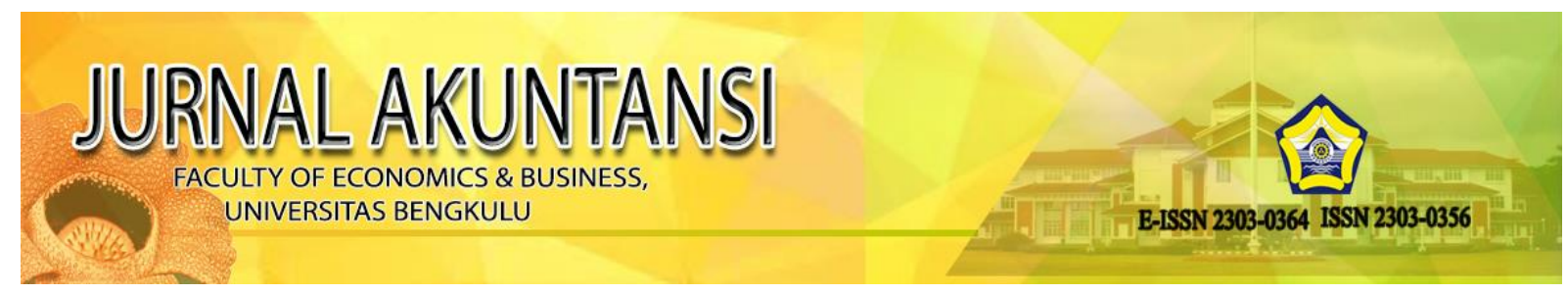

\title{
NIAT MAHASISWA AKUNTANSI BERKARIR SEBAGAI AKUNTAN DI LUAR NEGERI: PENGUJIAN THEORY OF PLANNED BEHAVIOR
}

\author{
Madani Hatta ${ }^{1)}$, Agustian Riduan O. H ${ }^{2)}$ \\ Fakultas Ekonomi dan Bisnis Universitas Bengkulu \\ madani.unib2006@gmail.com $^{\text {l) }}$ agustina@gmail.com $^{3)}$
}

\begin{abstract}
This study aimed to determine the factors that affect intention of accounting students career as an accountant abroad. By using TPB (Theory of Planned Behavior) model, intention of accounting students career as an accountant abroad is influenced by three factors: attitude toward behavior, subjective norm, and perceived behavioral control. Respondents in this study were diploma and undergraduate students in last semester with a number of 90 students of Department of Accounting, Faculty of Economics and Business, University in Bengkulu city. The method of collecting data in this study using a survey by distributing questionnaires to the respondents either directly or entrusted to the chairman of the accounting department at the university. The data was analyzed by using SmartPLS 3.0. The results show that attitude toward behavior and subjective norm have significant positive effect on intention of accounting students career as an accountant abroad, but perceived behavioral control have no effect on intention of accounting students career as an accountant abroad.
\end{abstract}

Keywords: Theory of planned behavior (TPB), attitude towards behavior, subjective norm, perceived behavioral control.

\section{PENDAHULUAN}

Era globalisasi yang terjadi saat ini, menciptakan kemudahan dalam integrasi dan komunikasi antar bangsa yang menyebabkan semakin majunya pola pikir, sehingga menciptakan kemudahan dalam berbagai bidang terutama bidang ekonomi. Pada tahun 2015, para pemimpin ASEAN mendeklarasikan bahwa MEA merupakan tujuan integraasi ekonomi regional (Bali Concord II). Ada lima elemen utama ketika kawasan ASEAN menjadi pasar tunggal dan basis produksi, yaitu aliran bebas barang, aliran bebas jasa, aliran bebas investasi dan modal,dan aliran bebas tenaga kerja yang terampil. Berdasarkan hal tersebut maka disusunlah Mutual Recognition Arrangement (MRA) sebagai upaya mendukung arus bebas tenaga kerja professional, memfasilitasi pergerakan tenaga kerja yang didasarkan pada suatu kontrak perjanjian untuk mendukung kegiatan perdagangan dan investasi di sektor jasa. MRA sendiri dapat diartikan sebagai kesepakatan yang diakui oleh seluruh Negara ASEAN dimana antar Negara ASEAN saling mengakui dan menerima beberapa atau semua aspek hasil penilaian seperti hasil tes atau berupa sertifikat sehingga mendapat suatu kesetaraan dan mengakui adanya perbedaan antar negara untuk pendidikan, pelatihan, pengalaman dan persyaratan lisensi untuk para professional yang ingin berpraktik.

Pada bidang jasa akuntansi pemimpin ASEAN juga mengeluarkan ASEAN Mutual Recognition Arrangement Framework on Accountancy Services (AMRAs) untuk memfasilitasi perundingan MRAs di Jasa Akuntansi antar negara anggota ASEAN serta mempromosikan aliran informasi yang relevan dan bertukar keahlian, pengalaman dan praktik terbaik sesuai dengan kebutuhan spesifik masing-masing negara anggota ASEAN. Persetujuan ini mengakui hak setiap negara anggota ASEAN untuk mengatur pasokan sektor 
jasa akuntansi dalam wilayahnya, mencatat berbagai tingkat perkembangan jasa akuntansi di antara negara anggota ASEAN dan setuju untuk mendorong negara-negara anggota ASEAN yang siap, untuk masuk ke dalam perundingan bilateral atau multilateral MRAs di sektor jasa akuntansi. Persetujuan tersebut mensyaratkan adanya penghapusan aturan-aturan dan batasan yang sebelumnya menghalangi perekrutan tenaga kerja asing di lingkungan ASEAN.

Profesi akuntan merupakan salah satu profesi yang disepakati oleh para Menteri Ekonomi Asean pada program MRA ini. Dalam menghadapi hal ini Indonesia menerbitkan dan memberlakukan PMK 25/PMK/01/2014 dan pelaksanaan 10 Action plan. Hal ini merupakan bagian dari proses yang berkelanjutan dalam program IFAC Member Body Compliance untuk mendukung pembangunan berkelanjutan dan peningkatan profesi akuntansi di seluruh dunia. Action Plan disusun oleh anggota dan rekan untuk mereka gunakan sendiri didasarkan pada kerangka kerja nasional, prioritas, proses dan tantangan spesifik untuk setiap yurisdiksi. Pemerintah dan IAI telah bersama-sama merumuskan paket kebijakan yang matang dalam menghadapi liberalisasi jasa di ASEAN.

Masyarakat Ekonomi ASEAN (MEA) membuka peluang maupun tantangan bagi akuntan Indonesia, karena selain akuntan Indonesia memiliki peluang berkarir di negara lain kawasan ASEAN, akuntan asing juga memiliki peluang untuk berkarir di negara lain anggota ASEAN. Di era MEA, profesi akuntan tetap menjadi daya tarik bagi mahasiswa jurusan akuntansi baik itu program studi S1 maupun D3, walaupun dapat dinilai bahwa persaingan untuk menjadi akuntan semakin berat. Profesi Akuntan terbagi menjadi akuntan publik, akuntan intern, akuntan pemerintah, dan akuntan pendidik. Profesi akuntan juga menjadi menarik karena besarnya gaji seorang akuntan di Indonesia, yang mencapai 3-30 juta perbulannya. Gaji seorang akuntan di Indonesia dan negara anggota ASEAN lainnya tentu saja berbeda karena setiap negara memiliki aturan sendiri dalam penentuan gaji minimum di negara mereka masing-masing. Berdasarkan data survey yang dilakukan Numbeo, gaji seorang pegawai di Indonesia berada di peringkat delapan dari sepuluh negara anggota ASEAN, sehingga dapat disimpulkan bahwa gaji seorang akuntan di luar negeri tentu saja lebih besar dari gaji seorang akuntan di Indonesia.

Profesi akuntan juga memiliki prospek yang baik di masa depan karena peluang kerja yang terbuka lebar, baik di dalam negeri maupun di luar negeri. Jumlah akuntan di negaranegara ASEAN terbilang sedikit jika dibandingkan jumlah penduduk dan kebutuhan akuntan disetiap Negara (IAI dan www.asean.org). Hal ini menunjukkan. bahwa profesi sebagai akuntan di kawasan ASEAN masih sedikit sehingga profesi akuntan sangat dibutuhkan di kawasan ASEAN.

Profesi akuntan dalam ketentuan MRA, wajib memiliki kompetensi yang dibuktikan dengan sertifikasi kompetensi yang berlaku internasional yaitu Chartered Accountant $(C A)$. Akuntan maupun calon akuntan Indonesia memiliki peluang yang besar apabila akuntan Indonesia memiliki kompetensi yang mencukupi, serta soft skill yang sangat baik seperti bahasa, teknologi dan leadership dan juga akuntan yang berkompeten bebas bekerja di negara ASEAN lainnya yang memberikan imbalan dan jaminan masa depan yang lebih baik dibandingkan perusahaan/institusi yang ada di Indonesia. Namun peluang tersebut tidak lepas dari hambatan yang mungkin bisa terjadi. Hambatan dapat terjadi dari faktor internal maupun eksternal, hambatan faktor internal berasal dari individu akuntan itu sendiri, sebagai contoh hambatan terjadi ketika seorang akuntan tidak sanggup untuk mengikuti keadaan yang berubah, tidak siap dengan perubahan sehingga akan tertinggal dari akuntan yang lain (kurangnya kompetensi, mental dan soft skill). Hambatan faktor eksternal berasal dari luar individu akuntan,dapat berasal dari lingkungan (tempat tinggal, kerja,organisasi), dan orang lain.

Dalam menghadapi persaingan tersebut akuntan Indonesia harus memiliki strategi karena untuk bersaing tidak cukup mengandalkan kompetensi yang dimiliki saat ini. Strategi 
tersebut seperti mengembangkan soft skills, memiliki keunggulan kompetitif dibandingkan akuntan lainnya, membangun jaringan yang kuat dan luas antara individu dan institusi, mempersiapkan mental, memiliki sertifikasi akuntan professional,serta memiliki integritas yang tinggi.

Theory of Planned Behavior (TPB) adalah model berbasis niat (intention) yang dikembangkan oleh Ajzen (1991). Teori ini merupakan pengembangan dari Theory of Reasoned Action (TRA) yang dikenalkan oleh Fishbein (1967) dan kemudian dikembangkan oleh Ajzen dan Fishbein (1975). Teori ini merupakan teori yang digunakan untuk menjelaskan maksud seseorang untuk melakukan perilaku tertentu. Niat merupakan indikasi seberapa keras seseorang bersedia untuk mencoba berbagai upaya mereka merencanakan untuk melakukan perilaku (behaviors) (Ajzen dan Driver, 1992). Niat ini ditentukan oleh sejauh mana individu memiliki sikap positif pada perilaku tertentu, dan sejauh mana jika dia memilih untuk melakukan perilaku tertentu itu diamendapat dukungan dari orang-orang lain yang berpengaruh dalam kehidupannya serta kemudahan atau kesulitan yang dia rasakan untuk melakukan perilaku tertentu.

Penelitian ini menggunakan pendekatan TPB untuk melihat apakah niat mempengaruhi mahasiswa akuntansi untuk berkarir sebagai akuntan di luar negeri, sejalan dengan fenomena MEA yang terjadi saat ini. Menurut TPB, seseorang dapat berindak berdasarkan niatnya hanya jika ia memilih kontrol terhadap perilakunya (Ajzen, 2002). Ajzen (1991) menjelaskan ada tiga faktor penentu niat yaitu (1) sikap terhadap perilaku (attitude toward behavior control), (2) norma-norma subjektif mengenai perilaku (Subjective Norm), dan (3) kontrol perilaku persepsian mengenai perilaku tersebut (perceived behavior control).

Alasan peneliti melakukan penelitian ini adalah karena masih sedikit penelitian mengenai niat mahasiswa akuntansi berkarir sebagai akuntan di luar negeri dengan pendekatan TPB di era MEA. Peneliti dalam penelitian ini ingin melihat bagaimana niat di dalam pendekatan TPB mempengaruhi mahasiswa akuntansi berkarir sebagai akuntan di luar negeri, dengan melihat dari beberapa hal yaitu sikap terhadap suatu perilaku, norma subjektif, dan kontrol perilaku persepsian atas perilaku tersebut.

Sikap terhadap perilaku dapat didefinisikan sebagai tingkat positif atau negatif individu terhadap suatu perilaku. Dalam hal ini individu secara umum akan menilai apakah suatu perilaku akan berdampak positif maka individu tersebut akan bersikap menyenangkan, sedangkan sebaliknya apabila suatu perilaku dipandang berdampak negatif maka individu akan bersikap menolak. Hal berikutnya yang mempengaruhi niat adalah norma subyektif. Di dalam hal ini TPB memperhatikan elemen sosial dari perilaku individu melalui norma subyektif ini (Ajzen; dikutip dalam Yuliana, 2004). Secara spesifik, dalam TPB, norma subyektif tentang suatu perilaku didefinisikan sebagai persepsi individu tentang tekanan sosial untuk melakukan atau tidak melakukan suatu perilaku.

Hal yang terakhir adalah kontrol perilaku persepsian (perceived behavior control). Secara spesifik, dalam TPB, kontrol perilaku yang persepsian didefinisikan sebagai persepsi individu mengenai kemudahan atau kesulitan untuk melakukan sesuatu perrilaku. Kontrol perilaku persepsian ditentukan oleh kombinasi antara belief individu mengenai faktor pendukung atau faktor penghambat untuk melakukan suatu perilaku (control beliefs), dengan kekuatan perasaan individu akan setiap faktor pendukung atau penghambat tersebut (perceived power control). Dalam hal ini individu akan melihat peluang dalam melakukan suatu perilaku dengan melihat faktor pendukung dan faktor penghambatnya. Tujuan penelitian ini untuk membuktikan masing-masing pengaruh sikap terhadap perilaku, norma subjektif dan kontrol perilaku persepsian terhadap niat mahasiswa akuntansi berkarir sebagai akuntan di luar negeri. 


\section{KERANGKA TEORITIS DAN HIPOTESIS}

\section{Theory of Planned Behavior}

Theory of Planned Behavior (TPB) merupakan pengembangan lebih lanjut dari Theory of Reasoned Action (TRA) (Ajzen, 1991 dan Jogiyanto, 2007). Ajzen mengembangkan teori TPB dengan menambahkan konstruk yang belum ada di TRA yaitu kontrol perilaku persepsian. TPB secara eksplisit mengenal kemungkinan bahwa banyak perilaku yang tidak semuanya di bawah kontrol penuh individu sehingga konsep dari kontrol perilaku persepsian ditambahkan untuk menangani perilaku-perilaku semacam ini. Model dari TPB menurut Ajzen (1991) mengandung berbagai variabel yaitu :

\section{Niat (Intention)}

Niat didefinisikan sebagai keinginan untuk melakukan perilaku. Niat tidak selalu statis dan dapat berubah seiring berjalannya waktu (Jogiyanto, 2007). Niat erat kaitannya dengan motivasi, yaitu dorongan yang timbul pada diri seseorang secara sadar atau tidak sadar untuk melakukan sesuatu tindakan dengan tujuan tertentu. Niat yang baik akan mendorong timbulnya motivasi untuk berbuat baik. Tindakan yang baik akan memberikan hasil yang baik apabila terus diulang maka akan terinternalisasi dan persistent dalam diri seseorang sehingga tercipta pribadi dengan perilaku yang baik, begitu pula sebaliknya (Suharto, 2008 dalam Miladia, 2010). Niat tidak selalu statis dan dapat berubah seiring berjalannya waktu sehingga dapat disimpulkan semakin lebar interval waktu, semakin mungkin terjadi perubahan pada niat (Jogiyanto, 2007). Dalam TPB, perilaku yang ditampilkan oleh individu timbul karena adanya niat untuk berperilaku(behavioral intention) (Jogiyanto, 2007). Niat berperilaku ditentukan oleh tiga macam kepercayaan, antara lain:

a) Kepercayaan perilaku (behavioral belief), yaitu kepercayaan tentang kemungkinan terjadinya perilaku. Kepercayaan perilaku akan menghasilkan suatu sikap menyukai atau tidak menyukai terhadap perilaku.

b) Kepercayaan normatif (normative belief), yaitu kepercayaan tentang ekspektasi normatif dari orang lain dan motivasi untuk menyetujui ekspektasi tersebut. Kepercayaan normatif menghasilkan tekanan sosial atau norma subjektif.

c) Kepercayaan kontrol (control belief), yaitu kepercayaan tentang keberadaan faktorfaktor yang akan memfasilitasi atau merintangi kinerja dari perilaku dan kekuatan persepsian dari faktor-faktor tersebut. Kepercayaan kontrol akan menghasilkan kontrol perilaku persepsian.

\section{Sikap terhadap Perilaku}

Fishbein dan Ajzen (1980) mendefinisikan sikap (attitudes) sebagai evaluasi individual dari keuntungan atau kerugian dari suatu objek sikap. Menurut mereka, sikap merupakan keyakinan seseorang tentang hasil yang akan ditimbulkan dari keterlibatan dalam perilaku tertentu. Sikap terhadap perilaku mengacu pada persepsi keinginan pribadi untuk melakukan perilaku (Ajzen, 1987). Sikap ditentukan melalui keyakinan seseorang tentang perilaku dan konsekuensi atau evaluasi hasil dari melakukan perilaku tersebut (Bobek dan Hatfield, 2003). Sikap individu terhadap perilaku mencerminkan sejauh mana seseorang memiliki persepsi positif atau negatif dari perilaku tersebut (Tan dan Laswad, 2006).

Sikap mewakili perasaan umum seseorang mengenai favorableness atau unfavorableness terhadap perilaku (Fishbein dan Ajzen, 1975). Sikap seseorang terhadap suatu obyek adalah perasaan mendukung atau memihak (favorable) maupun perasaan tidak mendukung atau tidak memihak (unfavorable) pada obyek tersebut (Mustikasari, 2007). Seseorang yang memiliki keyakinan bahwa melakukan suatu tingkah laku akan menghasilkan hal yang positif akan memiliki sikap yang favorable untuk melakukan suatu perilaku 
tersebut. Dengan keyakinan bahwa berprofesi sebagai praktisi akuntansi akan memberikan hasil yang positif dan membawa keuntungan, maka hal ini akhirnya membuat mahasiswa akuntansi memiliki sikap mendukung atau menyetujui untuk memilih profesi sebagai praktisi akuntansi dan dari sini akan menimbulkan niat untuk berprofesi sebagai praktisi akuntansi.

\section{Norma Subjektif}

Norma subjektif (subjective norm) adalah persepsi atau pandangan seseorang terhadap kepercayaan-kepercayaan orang lain yang akan memengaruhi niat untuk melakukan atau tidak melakukan perilaku yang sedang dipertimbangkan. Ajzen (1991) menyatakan bahwa norma subjektif lebih mengacu pada pengertian tentang persepsi atas tekanan sosial untuk melakukan atau tidak melakukan suatu perilaku. Dalam beberapa penelitian, norma subjektif dinyatakan sebagai personal atau moral norm, parental influence, human factor, human influences, atau influence of significant people (Ajzen, 1991; Sugahara dan Boland, 2006; dan Law, 2010).

Norma subjektif yang berupa penentu kedua dari niat, juga diasumsikan sebagai suatu fungsi kepercayaan yaitu kepercayaan seseorang bahwa individu-individu tertentu atau kelompok-kelompok menyetujui atau tidak menyetujui melakukan suatu perilaku. Jika menjadi suatu titik referensi untuk mengarahkan perilaku, individu atau kelompok tersebut disebut referents. Referents yang penting termasuk orang tua, pasangan, teman dekat, teman kerja, dan pakar profesional (semacam akuntan) (Jogiyanto, 2007). Manusia yang percaya kepada kebanyakan referent yang memotivasi mereka untuk menaatinya dan berpikir seharusnya melakukan suatu perilaku, dikatakan menerima tekanan sosial untuk melakukan perilaku tersebut. Sebaliknya, manusia yang percaya bahwa kebanyakan referent yang membuat mereka termotivasi untuk menaatinya tetapi tidak setuju untuk melakukan suatu perilaku akan memiliki suatu norma subjektif yang meletakkan tekanan pada mereka untuk menghindari melakukan perilaku tersebut.

\section{Kontrol Perilaku Persepsian}

Menurut TPB, banyak perilaku tidak semuanya di bawah kontrol penuh individual sehingga perlu ditambahkan konsep kontrol perilaku persepsian (Jogiyanto, 2007). Kontrol perilaku persepsian didefinisikan oleh Ajzen (1991) sebagai kemudahan atau kesulitan dalam persepsi untuk melakukan perilaku. Kontrol perilaku persepsian ini merefleksikan pengalaman masa lalu dan mengantisipasi halangan-halangan yang ada sehingga semakin menarik sikap dan norma subjektif terhadap perilaku, semakin besar kontrol perilaku persepsian, semakin kuat pula niat seseorang untuk melakukan perilaku yang sedang dipertimbangkan.

TPB mengasumsikan bahwa kontrol perilaku persepsian memiliki implikasi motivasional terhadap niat (Achmat, 2010). Orang-orang yang percaya apabila mereka tidak memiliki sumber daya yang ada dan kesempatan untuk melakukan perilaku tertentu, mungkin tidak akan membentuk niat-niat perilaku yang kuat untuk melakukannya meskipun mereka memiliki sikap yang positif terhadap perilakunya dan percaya bahwa orang lain akan menyetujui seandainya mereka melakukan perilaku tersebut. Kontrol perilaku persepsian yang telah berubah akan memengaruhi perilaku yang ditampilkan sehingga tidak sama lagi dengan yang diniatkan.

\section{Masyarakat Ekonomi ASEAN (MEA)}

Association of Southeast Asian Nation (ASEAN) merupakan sebuah organisasi geopolitik dan ekonomi dari negara-negara di kawasan Asia Tenggara. ASEAN dibentuk pada tanggal 8 agustus 1967 berdasarkan Deklarasi Bangkok. Dalam upaya menempa integrasi dan kerjasama yang lebih solid diantara negara-negara anggota, ASEAN melangkah lebih lanjut 
dengan merumuskan sebuah proyek besar yakni menciptakan Masyarakat Ekonomi ASEAN (MEA). Masyarakat Ekonomi ASEAN (MEA) secara resmi ditetapkan pada Konferensi Tingkat Tinggi (KTT) IX di Bali tahun 2003.

Para pemimpin ASEAN mendeklarasikan bahwa Masyarakat Ekonomi ASEAN merupakan tujuan integrasi ekonomi regional (Bali Concord II) pada tahun 2015. MEA akan ditopang oleh tiga pilar yang akan saling mengikat dan memperkuat dalam upaya mewujudkan kemakmuran, stabilitas, keamanan, perdamaian dan peningkatan kerjasama di antara negara-negara kawasan ASEAN di segala bidang. Dengan terbentuknya MEA, terbuka peluang bagi peningkatan kerjasama baik di bidang politik, keamanan, ekonomi dan sosialkebudayaan secara komprensif. Tidak hanya itu, dengan terbentuknya MEA, maka ASEAN diharapkan dapat berdiri sejajar dengan komunitas-komunitas regional lainnya seperti Uni Eropa dan lain-lain (Direktorat Jenderal Kerjasama ASEAN, 2013). Dengan adanya MEA, kawasan ASEAN akan menjadi pasar tunggal dan basis produksi yang memiliki lima elemen utama, yaitu aliran bebas barang, aliran bebas jasa, aliran bebas investasi dan modal, serta aliran bebas tenaga kerja yang terampil.

Aliran bebas sektor jasa merupakan salah satu elemen penting dalam pemberlakuan MEA, yang di dalamnya tidak ada hambatan bagi para pemasok jasa di kawasan ASEAN dalam penyediaan jasanya secara lintas-negara, sesuai dengan aturan domestik di setiap negara-negara di ASEAN. Dalam memfasilitasi aliran bebas sektor jasa pada era MEA nantinya, ASEAN telah mempersiapkan pengakuan terhadap kualifikasi para pekerja profesional, dengan tujuan memfasilitasi pergerakannya di kawasan ASEAN.

\section{Mutual Recogniton Arrangement (MRA)}

Untuk mendukung dalam memfasilitasi pergerakan tenaga kerja professional yang didasarkan pada suatu kontrak/perjanjian dalam kegiatan perdagangan dan investasi sektor jasa, seluruh pemimpin ASEAN menyusun Mutual Recogniton Arrangement (MRA). Disusunnya MRA sebagai upaya untuk mendukung arus bebas tenaga kerja profesional, memfasilitasi pergerakan tenaga kerja yang didasarkan pada suatu kontrak perjanjian untuk mendukung kegiatan perdagangan dan investasi di sektor jasa.

MRA sendiri dapat diartikan sebagai kesepakatan yang diakui oleh seluruh negaranegara di ASEAN yang saling mengakui dan menerima beberapa atau semua aspek hasil penilaian seperti hasil tes atau berupa sertifikat dengan tujuan menciptakan prosedur mekanisme akreditasi sehingga mendapat suatu kesetaraan dan mengakui adanya perbedaan antar negara untuk pendidikan, pelatihan, pengalaman dan persyaratan lisensi untuk para pekerja professional yang ingin berpraktek di kawasan ASEAN. Sampai tahun 2009, yang telah disepakati oleh ASEAN yaitu MRA untuk jasa-jasa teknisi, perawat, arsitektur, penyurvei/pemetaan, dokter umum, dokter gigi, akuntan, dan kepariwisataan. Semua MRA ini ditandatangani oleh para Menteri Ekonomi dari negara-negara di ASEAN (Abda'I, 2014).

Dalam pemberlakuan MEA pada akhir tahun 2015 nantinya, maka dipastikan akan terbuka kesempatan kerja seluas-luasnya. Tenaga kerja profesional dapat keluar dan masuk dari satu negara ke negara lain mendapatkan pekerjaan tanpa adanya hambatan di negara yang dituju. Selain itu, dengan pembentukan MRA untuk jasa-jasa tenaga kerja profesional termasuk akuntan, maka terbuka kesempatan yang besar tanpa hambatan yang menghalangi bagi akuntan di Indonesia termasuk lulusan Jurusan Akuntansi untuk berkarir sebagai akuntan di kawasan ASEAN. Pada pemberlakuan era MEA, seorang akuntan profesional dalam negara-negara kawasan ASEAN bisa mendaftar sebagai seorang akuntan professional yang legal dan dengan demikian akan memenuhi syarat untuk bekerja atau melakukan praktek di kawasan ASEAN. Namun, tantangan profesi akuntansi semakin kompetitif dengan diberlakukannya MEA pada tahun akhir tahun 2015. 


\section{Pengembangan Hipotesis}

\section{Sikap terhadap perilaku dan niat berkarir sebagai akuntan di luar negeri}

Ajzen (2005) memaparkan sikap terhadap suatu perilaku merupakan suatu fungsi yang didasarkan oleh keyakinan, yaitu mengenai konsekuensi positif dan atau negatif yang akan diperoleh individu dari melakukan suatu perilaku (salient outcome beliefs). Secara umum, semakin individu memiliki penilaian bahwa suatu perilaku akan menghasilkan konsekuensi positif maka individu akan cenderung bersikap favorable terhadap perilaku tersebut, sebaliknya semakin individu memiliki penilaian bahwa suatu perilaku akan menghasilkan konsekuensi negatif maka individu akan cenderung bersikap unfavorable terhadap perilaku tersebut (Ajzen, 2005). Sikap terhadap perilaku akan mempengaruhi niat mahasiswa akuntansi untuk berkarir sebagai akuntan di luar negeri karena, pandangan positif yang diterima mahasiswa akuntansi mengenai profesi akuntansi, yang dipandang memiliki karir yang jelas dan penghasilan yang tinggi, memiliki nilai prestise, masa kerja yang panjang serta didukung oleh pendidikan profesi akuntansi yang dapat meningkatkan karir sebagai akuntan.

Penelitian mengenai pengaruh TPB terhadap niat yang dilakukan oleh Solikah (2014) menunjukkan bahwa sikap terhadap perilaku mempengaruhi niat untuk mengejar karir CPA yang didasari keuntungan dalam peningkatan karir sebagai akuntan. Hasil penelitian ini sejalan dengan penelitian terdahulu yang dilakukan oleh Felton et al. (1995). Felton et al. (1995) membuktikan bahwa mahasiswa yang berniat menjadi chartered accountant memiliki sikap yang positif terhadap karier pada profesi tersebut. Penelitian diatas telah membuktikan bahwa persepsi dan sikap mahasiswa terhadap suatu profesi mampu digunakan untuk memprediksi niat mereka menjalani suatu karier. Berdasarkan uraian diatas maka penulis dapat merumuskan hipotesis.

$\mathrm{H}_{1}$ : Sikap terhadap perilaku berpengaruh positif terhadap niat mahasiswa akuntansi berkarir sebagai akuntan di luar negeri.

\section{Norma subyektif dan niat mahasiswa berkarir sebagai akuntan di luar negeri}

Ajzen (2005) memaparkan norma subyektif merupakan fungsi yang didasarkan oleh belief yang disebut sebagai normative beliefs, yaitu beliefs mengenai kesetujuan dan atau ketidaksetujuan seorang maupun kelompok yang penting bagi individu terhadap suatu perilaku (salient referent beleiefs). Ajzen (2005) menambahkan, pada beberapa perilaku, runjukan sosial yang dianggap penting juga memasukan rujukan sosial yang berasal dari orang tua, pasangan, sahabat, dosen dan teman-teman di kampus, dan rujukan lain yang berhubungan dengan suatu perilaku. Mauldin, Crain, dan Mounce (2000) mengemukakan bahwa guru harus memberi pengaruh penting pada keputusan siswa untuk mengejar kualifikasi akuntansi. Kontribusi dari opini dari setiap rujukan yang diberikan ditimbang dengan motivasi bahwa seorang individu harus mematuhi keinginan dari rujukan tersebut. Dorongan dari luar seperti pengaruh orang tua, dukungan pasangan, dan guru mendorong akan mempengaruhi niat untuk mengejar karir CPA. Penelitian Badingatus Solikhah (2014) menjelaskan bahwa norma subyektif mempengaruhi niat untuk mengejar karir sebagai CPA. Sulistiani (2012) juga menjelaskan faktor norma subjektif memiliki pengaruh yang signifikan terhadap niat mahasiswa akuntansi untuk berkarier sebagai akuntan publik.

Secara umum, semakin individu mempersiapkan bahwa rujukan sosialnya merekomendasikan untuk melakukan suatu perilaku maka individu akan cenderung merasakan tekanan sosial untuk melakukan perilaku tersebut; sebaliknya semakin individu mempersepsikan bahwa rujukan sosialnya merekomendasikan untuk tidak melakukan suatu perilaku maka individu akan cenderung merasakan tekanan sosial untuk tidak melakukan perilaku tersebut (Ajzen, 2005). Norma subyektif mempengaruhi niat mahasiswa berkarir sebagai akuntan di luar negeri, karena seorang mahasiswa akuntansi yang akan berprofesi 
sebagai akuntan akan mendengarkan pendapat dari orang tua, rekan, sahabat, keluarga atau sekelompok tertentu untuk mengambil keputusan, mengingat hal-hal positif yang akan didapatkan apabila menjadi akuntan di luar negeri. Berdasarkan uraian di atas maka penulis dapat merumuskan hipotesis kedua sebagai berikut:

$\mathrm{H}_{2}$ : Norma Subyektif berpengaruh positif terhadap niat mahasiswa akuntansi berkarir sebagai akuntan.

\section{Kontrol perilaku persepsian dan niat mahasiswa berkarir sebagai akuntan di luar negeri}

Ajzen (2006) memaparkan kontrol perilaku persepsian sebagai fungsi yang didasarkan oleh belief yang disebut sebagai control beliefs, yaitu belief individu mengenai faktor pendukung dan atau penghambat untuk melakukan suatu perilaku didasarkan pada pengalaman terdahulu individu tentang suatu perilaku, informasi yang dimiliki individu tentang suatu perilaku yang diperoleh dengan melakukan observasi pada pengetahuan yang memiliki diri maupun orang lain yang dikenal individu, dan juga oleh berbagai faktor lain yang dapat meningkatkan ataupun menurunkan perasaan individu mengenai tingkat kesulitan dalam melakukan suatu perilaku.

Penelitian Solikhah (2015) mengasumsikan bahwa kontrol perilaku persepsian ditentukan oleh total set control belief yang ada. Kontrol perilaku persepsian mempengaruhi niat. Dalam kombinasi, sikap terhadap perilaku, norma subyektif, dan kontrol perilaku persepsian mengarah pada pembentukan niat perilaku. Sebagai aturan umum, semakin menguntungkan sikap dan norma subjektif, dan semakin besar kontrol yang dirasakan, mengakibatkan semakin kuat niat seseorang untuk mengejar karir sebagai CPA. Sugahara dan Boland (2006) juga menjelaskan bahwa suatu perilaku akan dilakukan setelah mempertimbangkan adanya opportunity cost. Lebih lanjut, niat mahasiswa untuk berkarier sebagai certified public accountant (CPA) dapat diprediksi dengan mengetahui persepsi mereka terhadap cost untuk menjadi CPA. Kedua penelitian di atas menjelaskan bahwa kontrol perilaku persepsian mempengaruhi niat mahasiswa untuk melakukan suatu perilaku, maka demikian pula kontrol perilaku persepsian dapat mempengaruhi niat mahasiswa akuntansi untuk berkarir sebagai akuntan di luar negeri.

Kontrol perilaku persepsian mempengaruhi niat mahasiswa berkarir sebagai akuntan di luat negeri, karena seorang mahasiswa akuntansi yang akan berprofesi sebagai akuntan akan menjalani pendidikan profesi akuntansi sebagai faktor pendukung untuk menunjang karir sebagai akuntan professional. Namun disisi lain ada beberapa faktor lain yang akan menjadi penghambat bagi mahasiswa akuntansi untuk berkarir sebagai akuntan seperti perbedaan budaya, bahasa, kondisi alam, kondisi suatu negara (politik dan ekonomi). Kedua faktor tersebut akan menjadi pertimbangan bagi mahasiswa tersebut, karena walaupun beberapa faktor penghambat mungkin dapat teratasi seperti mengikuti kursus bahasa asing, dan meningkatkan kemampuan soft skill, namun faktor penghambat lain seperti budaya, kondisi alam, dan kondisi suatu negara tidak dapat diatasi begitu saja, harus ada proses adaptasi dari individu tersebut. Berdasarkan uraian di atas maka penulis dapat merumuskan hipotesis ketiga sebagai berikut:

$\mathrm{H}_{3}$ : Kontrol perilaku persepsian berpengaruh negatif terhahap niat mahasiswa akuntansi berkarir sebagai akuntan.

\section{METODE PENELITIAN}

Penelitian digolongkan kedalam penelitian kauntitatif dengan metode survey, yaitu penelitian yang dilakukan pada populasi beesar maupun kecil tetapi data yang dipelajari adalah data dari sampel yang diambil dari populasi tersebut dengan menggunakan kuesioner. 
Jenis penelitian ini disebut kausatif yaitu hubungan yang bersifat sebab akibat yang menggambarkan fakta-fakta yang terjadi secara jelas dan melihat pengaruh dari masingmasing variabel penyebab dan variabel terikat( Sugiyono, 2012).

Variabel dependen dalam penelitian ini adalah niat mahasiswa akuntansi untuk berkarier sebagai akuntan di luar negeri. Dalam penelitian ini, terdapat tiga variabel independen yaitu sikap terhadap perilaku, norma subjektif dan kontrol perilaku persepsian.

Niat mahasiswa akuntansi untuk berkarier sebagai akuntan di luar negeri didefinisikan sebagai niat yang dimiliki oleh mahasiswa akuntansi untuk memilih karier sebagai akuntan di luar negeri setelah lulus sebagai sarjana ekonomi. Pada penelitian ini, indikator pertanyaan pada variabel niat mahasiswa akuntansi untuk berkarier sebagai akuntan di luar negeri diadopsi berdasarkan instrument penelitian yang telah dikembangkan oleh Amin et al. (2009). Indikator pertanyaan pada variabel niat mahasiswa akuntansi untuk berkarier sebagai akuntan diluar negeri terdiri dari empat butir pertanyaan mengenai seberapa tinggi intensitas niat dan niat berperilaku mahasiswa akuntansi untuk berkarir sebagai akuntan di luar negeri setelah lulus.

Variabel sikap terhadap perilaku didefinisikan sebagai kumpulan keyakinan seseorang (beliefs) tentang suatu perilaku. Variabel sikap terhadap perilaku diukur dengan pertanyaan berdasarkan instrument penelitian Amin et al. (2009). Indikator pertanyaan pada variabel sikap mahasiswa akuntansi untuk berkarier sebagai akuntan diluar negeri terdiri dari sepuluh butir pertanyaan mengenai seberapa tinggi sikap terhadap perilaku mempengaruhi niat mahasiswa akuntansi untuk berkarir sebagai akuntan di luar negeri.

Variabel norma subjektif didefinisikan sebagai persepsi individu terhadap tekanan sosial yang dirasakan untuk melakukan atau tidak melakukan perilaku. Variabel Norma Subjektif diukur mengggunakan kuesioner dari penelitian Amin et al. (2009). Indikator pertanyaan variabel norma subjektif terdiri dari lima butir pertanyaan menggunakan skala likert lima poin.

Variabel kontrol perilaku persepsian didefinisikan sebagai persepsi kemudahan atau kesulitan melakukan perilaku. Variabel ini diukur mengggunakan kuesioner pertanyaan berdasarkan instrumen penelitian Amin et al. (2009). Indikator pertanyaan variabel kontrol perilaku persepsian terdiri dari sepuluh butir pertanyaan menggunakan skala likert lima poin.

Populasi dalam penelitian ini adalah Mahasiswa Akuntansi Strata Satu (S1) dan Diploma 3 (D3) Fakultas Ekonomi dari universitas-universitas yang ada di Kota Bengkulu. Total populasi dalam penelitian ini adalah disajikan pada Tabel 1 berikut:

Tabel 1

Populasi Penelitian

\begin{tabular}{c|l|c}
\hline No & \multicolumn{1}{|c}{ Responden Penelitian } & Jumlah mahasiswa \\
\hline 1 & Universitas Bengkulu & 536 \\
\hline 2 & Universitas Muhammadiyah Bengkulu & 203 \\
\hline 3 & Universitas Dehasen & 111 \\
\hline 4 & Universitas Prof. Dr. Hazairin, S.H & 30 \\
\hline & Total & 880 \\
\hline \multicolumn{2}{c}{ Sumber: Administrasi Jurusan Akuntansi (UNIB,UMB,UNIHAZ,UNIVED) }
\end{tabular}

Pengambilan sampel pada penelitian ini menggunakan random sampling method. Mahasiswa yang dipilih adalah mahasiswa akuntansi tingkat akhir yang belum bekerja atau sedang dalam proses pengerjaan skripsi yang diasumsikan akan segera lulus, sehingga dapat diperoleh informasi langsung mengenai faktor faktor yang melatarbelakangi niat berkarir sebagai akuntan di luar negeri. Formula yang digunakan untuk menentukan ukuran sampel adalah rumus slovin: 


$$
\mathrm{n}=\frac{N}{N\left(d^{2}\right)+1}
$$

Keterangan:

$\mathrm{n}=$ jumlah sampel

$\mathrm{N}=$ jumlah populasi

$\mathrm{d}=$ margin error

Dari rumus dan jumlah populasi diatas, maka jumlah sampel penelitian ini adalah:

$$
\begin{aligned}
& \mathrm{N}=880 \\
& \mathrm{~d}=10 \% \\
& \mathrm{n}=\frac{880}{880(0,1)^{2}+1} \\
& \mathrm{n}=89,79
\end{aligned}
$$

Dari hasil perhitungan sampel, sampel dalam penelitian ini berjumlah 89,79 mahasiswa atau dibulatkan menjadi 90 mahasiswa.

Data yang digunakan dalam penelitian ini adalah data primer yang diperoleh secara langsung dari sumber atau objek penelitian melalui kuesioner. Peneliti menggunakan metode survey dengan cara mendistribusikan kuesioner secara langsung pada responden, dan peneliti mendampingi responden dalam mengisi kuesioner agar tidak terjadi kesalahan dalam pengisian kuesioner. Sebelum diminta untuk mengisi kuesioner, terlebih dahulu peneliti menjelaskan mengenai penelitian serta isi kuesioner dan dijelaskan secara ringkas apa yang dimaksud niat mahasiswa akuntansi berkarir sebagai akuntan diluar negeri di dalam penelitian tersebut, sehingga diharapkan dapat membantu responden untuk bisa memahami setiap item pertanyaan dalam kuesioner tersebut. Pendistribusian kuesioner secara langsung sangat penting karena peneliti dapat melihat apakah responden penelitian memenuhi syarat untuk mengisi kuesioner, yaitu mahasiswa tingkat akhir program studi S1 dan D3 jurusan Akuntansi Kota Bengkulu.

Dalam penelitian ini analisis data menggunakan pendekatan Partial Least Square (PLS). PLS didefinisikan oleh dua persamaan, yaitu inner model dan outer model. Inner model menentukan spesifikasi hubungan antara konstrak dan konstrak yang lain, sedangkan outer model menentukan spesifikasi hubungan antara konstrak dan indikator-indikatornya. Outer Model (Model Pengukuran) digunakan untuk mengetahui validitas dan reliabilitas yang menghubungkan indikator dengan konstruk atau variabel latennya. Pengujian inner model atau model struktural dilakukan untuk melihat hubungan antara konstruk, nilai signifikansi dan $R$-square dari model penelitian. Pengujian hipotesis dilakukan dengan proses bootstrapping/ resampling bootstrapping. Pengujian hipotesis yang diajukan dapat dilihat dari besarnya nilai t-statistik. Kriteria untuk menolak dan menerima hubungan yang diajukan dapat dilihat dari perbandingan antar nilai t-statistik dan t-tabel. Jika nilai t-statistik > t-tabel, maka hipotesis yang diajukan diterima (Ghozali, 2014).

\section{HASIL DAN PEMBAHASAN}

Responden penelitian ini adalah mahasiswa tingkat akhir S1 dan D3 Jurusan Akuntansi di Kota Bengkulu. Data penelitian dikumpul dengan menyebarkan 90 kuesioner kepada mahasiswa jurusan akuntansi baik D3 dan S1 Akuntansi di Kota Bengkulu sesuai dengan jumlah sampel yang dibutuhkan dalam penelitian. Persebaran sampel terhadap universitas dalam penelitian ini menggunakan rumus proportional stratified sampling. Data mengenai persebaran sampel penelitian dapat dilihat pada Tabel 2 berikut ini: 
Tabel 2

Deskripsi sampel penelitian

\begin{tabular}{c|l|c}
\hline No & \multicolumn{1}{|c|}{ Universitas } & Jumlah responden \\
\hline 1 & Universitas Bengkulu & 50 \\
\hline 2 & Universitas Prof.Dr. Hazairin, SH, MH & 10 \\
\hline 3 & Universitas Muhammadiyah Bengkulu & 20 \\
\hline 4 & Universitas Dehasen & 10 \\
\hline & Jumlah & 90 \\
\hline
\end{tabular}

Sumber : Data Primer diolah, 2017

Kuesioner disebarkan dengan cara mengantar langsung kepada responden, dan juga menitip dengan pihak jurusan, serta teman yang merupakan mahasiswa dari universitas tersebut, setelah diisi kuesioner langsung dikumpulkan apabila disserahkan ke responden secara langsung atau diambil kemudian rata-rata 1 sampai 7 hari setelah kuesioner disebarkan apabila kuesioner dititipkan.. Waktu yang diperlukan untuk pengumpulan data selama 16 hari dari tanggal 24 Januari 2017 sampai 9 Februari 2017. Kuesioner yang telah dikirim kemudian dikumpulkan kembali untuk diolah. Rincian pengembalian kuesioner disajikan dalam Tabel 3 berikut ini:

Tabel 3

Rincian Pengiriman dan Pengembalian Kuesioner

\begin{tabular}{l|c|c}
\hline \multicolumn{1}{c|}{ Keterangan } & Jumlah & Persentase \\
\hline Total kuesioner yang disebar & 90 & $100 \%$ \\
\hline Totak kuesioner yang kembali & 90 & $100 \%$ \\
\hline Total kuesioner yang tidak dapat digunakan & 0 & $0 \%$ \\
\hline kuesioner yang dapat digunakan & 90 & $100 \%$ \\
\hline
\end{tabular}

Sumber : Data Primer diolah, 2017

Adapun profil 90 responden yang berpatisipasi dalam penelitian ini disajikan dalam Tabel berikut:

Tabel 4

Statistik Deskriptif responden

\begin{tabular}{c|c|c}
\hline Uraian & Frekuensi & Persentase \\
\hline Jenis Kelamin & & $54,44 \%$ \\
\hline Laki-Laki & 49 & $45,56 \%$ \\
\hline Perempuan & 41 & $100 \%$ \\
\hline Total & 90 & $1,11 \%$ \\
\hline Angkatan (tahun) & 1 & $5,55 \%$ \\
\hline 2011 & 5 & $87,78 \%$ \\
\hline 2012 & 79 & $5,55 \%$ \\
\hline 2013 & 5 & $100 \%$ \\
\hline 2014 & 90 & \\
\hline Total & & $93,33 \%$ \\
\hline Program Studi & 84 & \\
\hline S1 Reguler & & \\
\hline
\end{tabular}




\begin{tabular}{c|c|c}
\hline S1 Ekstensi & 1 & $1,11 \%$ \\
\hline D3 Reguler & 5 & $5,55 \%$ \\
\hline Total & 90 & $100 \%$ \\
\hline
\end{tabular}

Sumber : Data Primer diolah, 2017

Berdasarkan Tabel 4, dapat disimpulkan bahwa mayoritas responden adalah laki-laki yaitu sebanyak 49 orang $(54,44 \%)$, mayoritas responden adalah angkatan 2013 sebanyak 79 orang $(87,78 \%)$, dan responden mayoritas berasal dari program studi S1 Reguler. Hal ini menunjukkan bahwa responden penelitian ini telah memenuhi syarat yaitu mahasiswa tingkat akhir yang diasumsikan akan segera lulus dari program studi S1 maupun D3 Jurusan Akuntansi Kota Bengkulu.

Berdasarkan hasil statistik deskriptif setelah eliminasi terhadap beberapa instrumen pertanyaan yang tidak valid dari 90 responden, untuk variabel sikap terhadap perilaku memiliki rata-rata kisaran aktualnya sebesar 24,79 yang lebih tinggi dari rata-rata teoritis sebesar 18. Hal ini mengindikasikan bahwa mahasiswa jurusan akuntansi memiliki keyakinan bahwa berkarir sebagai akuntan di luar negeri akan memberikan hal yang positif bagi dirinya seperti, gaji yang tinggi, memiliki prestise di masyarakat, sehingga responden akan bersikap menyukai (favorable) sehingga mempengaruhi niat mahasiswa untuk berkarir sebagai akuntan di luar negeri.

Variabel norma subjektif memiliki rata-rata kisaran aktualnya sebesar 18,14 yang lebih tinggi dari rata-rata teoritis sebesar 15. Hal ini mengindikasikan bahwa mahasiswa jurusan akuntansi menilai orang-orang disekitar mereka, sebagai contoh ketika orang tua, teman dan sahabat memotivasi,serta dosen dan ahli akuntansi merekomendasikan berkarir sebagai akuntan di luar negeri adalah pilihan yang baik.

Variabel kontrol perilaku persepsian memiliki rata-rata kisaran aktualnya sebesar 11,70 yang lebih tinggi dari rata-rata teoritis sebesar 9. Hal ini mengindikasikan bahwa responden memandang adanya hambatan yang dirasakan, namun walaupun hambatan berkarir sebagai akuntan itu besar, responden tetap melihat peluang yang ada, memiliki keyakinan positif yang kuat dan sangat dipengaruhi oleh orang-orang disekitar mereka untuk berkarir sebagai akuntan di luar negeri.

Variabel niat berkarir sebagai akuntan di luar negeri memiliki rata-rata aktualnya sebesar 11,61 yang lebih tinggi dari rata-rata teoritis sebesar 9. Hal ini mengindikasikan bahwa responden memiliki niat untuk berkarir sebagai akuntan di luar negeri yang tinggi.

Dengan menggunakan SMART PLS 3,0, kemudian model diolah dengan menggunakan PLS Algorithm. Berikut ini tampilan hasil PLS Algorithm : 
Gambar 1

\section{Tampilan Hasil PLS Algorithm}

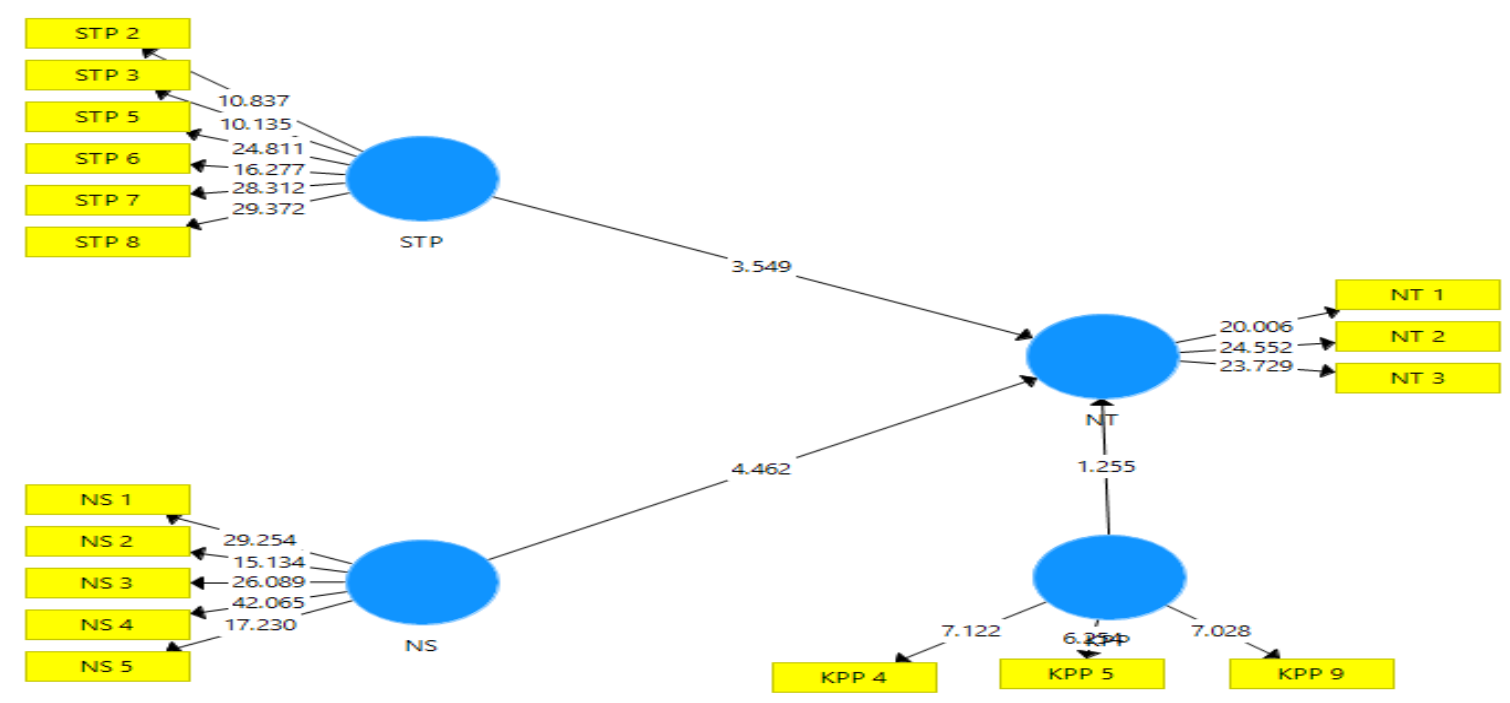

Sumber: data primer diolah, 2017

Gambar 1 di atas menunjukan bahwa semua indikator memiliki skor diatas 0,70 dan dapat disimpulkan bahwa konstruk telah memenuhi kriteria convergent validity yang baik. Nilai cross loading juga menunjukkan discriminant validity yang baik oleh karena nilai korelasi indikator terhadap konstruknya lebih tinggi dibandingkan nilai korelasi indikator dengan konstruk lainnya. Dari hasil output SmartPLS, semua konstruk memiliki nilai AVE dan Communality di atas 0,50. Jadi dapat disimpulkan bahwa konstruk memiliki validitas konvergen yang baik.

Selain uji validitas konstruk, dilakukan juga uji reliabilitas konstruk yang diukur dengan composite reliability dan diperkuat dengan cronbachs alpha dari blok indikator yang mengukur konstruk. Dari hasil output SmartPLS, semua konstruk memiliki nilai composite realibility diatas 0,70 dan cronbachs alpha diatas 0,6. Jadi dapat disimpulkan bahwa konstruk memiliki realibilitas yang baik. Selanjutnya dilakukan pengujian model struktural yang dievaluasi dengan menggunakan $R$-square untuk konstruk dependen (endogen) dan uji $t$ serta signifikansi dari koefisien parameter jalur struktural. Untuk nilai R-square konstruk dependen (endogen) dapat dilihat pada Tabel 5 berikut.

Tabel 5

R-Square

\begin{tabular}{l|c}
\hline \multicolumn{1}{c|}{ Variabel } & R Square \\
\hline Niat berkarir & 0,440 \\
\hline
\end{tabular}

Sumber: data primer diolah, 2017

Berdasarkan Tabel 5 di atas, model pengaruh sikap terhadap perilaku, norma subjektif dan kontrol perilaku persepsian terhadap niat berkarir sebagai akuntan memberikan nilai Rsquare sebesar 0,440 yang dapat diinterpretasikan bahwa variabilitas variabel niat berkarir sebagai akuntan di luar negeri, dipengaruhi oleh tiga variable yaitu, sikap terhadap perilaku, norma subjektif dan kontrol perilaku persepsian sebesar 44\%, sedangkan $56 \%$ pengaruh lainnya dijelaskan oleh variabel lain di luar variabel yang diteliti. 
Pengujian hipotesis dalam PLS secara statistik setiap hubungan yang dihipotesiskan dilakukan dengan menggunakan simulasi yaitu membandingkan nilai t-statistic dengan ttabel signifikansi $\alpha=5 \%(1,66)$. Jika nilai t-statistic $>$ t-tabel maka hipotesis di terima dan jika nilai t-statistic < t-tabel maka hipotesis ditolak. Dasar yang digunakan dalam menguji hipotesis adalah nilai yang terdapat pada Tabel 6 path coefficient berikut ini :

Tabel 6

Path Coefficient (Mean, STDEV, t-Values)

\begin{tabular}{l|l|l|l|l|l|l}
\hline Variabel & $\begin{array}{l}\text { Original } \\
\text { Sample (O) }\end{array}$ & $\begin{array}{l}\text { Sample } \\
\text { Mean (M) }\end{array}$ & $\begin{array}{l}\text { Standard } \\
\text { Deviation } \\
(\text { STDEV) }\end{array}$ & $\begin{array}{l}\text { t-statistics } \\
(\mid \text { O/STERR })\end{array}$ & t-tabel & Keterangan \\
\hline STP -> NT & 0,324 & 0,328 & 0,089 & 3,652 & 1,66 & Diterima \\
\hline NS -> NT & 0,388 & 0,386 & 0,091 & 4,279 & 1,66 & Diterima \\
\hline KPP ->NT & 0,095 & 0,111 & 0,075 & 1,272 & 1,66 & Ditolak \\
\hline
\end{tabular}

Sumber: data primer diolah, 2017

Dari Tabel 6 di atas menunjukkan bahwa variabel sikap terhadap perilaku berpengaruh terhadap niat mahasiswa akuntansi berkarir sebagai akuntan di luar negeri dengan koefisien sebesar 0,324. Nilai signifikansi dilihat berdasarkan hasil perhitungan tstatistic $(3,652)>\mathrm{t}$-tabel $(1,66)$ yang menunjukkan bahwa variabel sikap terhadap perilaku berpengaruh terhadap niat mahasiswa berkarir sebagai akuntan di luar negeri, sehingga hipotesis $\mathrm{H} 1$ dalam penelitian ini diterima.

Norma Subjektif berpengaruh terhadap niat berkarir sebagai akuntan di luar negeri dengan koefisien sebesar 0,388. Nilai signifikansi dilihat berdasarkan hasil perhitungan tstatistic $(4,279)>\mathrm{t}$-tabel $(1,66)$ yang menunjukkan bahwa variabel norma subjektif berpengaruh terhadap niat berkarir sebagai akuntan di luar negeri, sehingga hipotesis $\mathrm{H} 2$ dalam penelitian ini diterima.

Kontrol perilaku persepsian memiliki koefisien sebesar 0,095. Nilai signifikansi dapat dilihat berdasarkan hasil perhitungan t-statistic $(1,272)<\mathrm{t}$-tabel $(1,66)$ yang menunjukkan bahwa variabel kontrol perilaku persepsian tidak berpengaruh terhadap niat berkarir sebagai akuntan di luar negeri, sehinggan hipotesis $\mathrm{H} 3$ dalam penelitian ini ditolak.

\section{Sikap terhadap perilaku dan niat mahasiswa akuntansi berkarir sebagai akuntan di luar negeri}

Hipotesis pertama yang menyatakan sikap terhadap perilaku berpengaruh terhadap niat mahasiswa akuntansi berkarir sebagai akuntan di luar negeri secara empiris terbukti didukung. Hasil penelitian ini menunjukkan bahwa responden memiliki keyakinan bahwa berkarir sebagai akuntan di luar negeri akan memberikan hal yang positif bagi dirinya. Pandangan positif yang didapatkan oleh mahasiswa jurusan akuntansi adalah pandangan bahwa berkarir sebagai akuntan diluar negeri akan mendapatkan gaji yang lebih tinggi, memiliki nilai prestise di masyarakat, memberi kesempatan untuk lebih berkembang dibidang akuntansi dibandingkan berkarir sebagai akuntan di dalam negeri.

Hasil pengujian hipotesis satu menyatakan bahwa semakin besar hal positif yang diterima maka semakin besar pula niat mahasiswa jurusan akuntansi untuk berkarir sebagai akuntan di luar negeri. Hasil penelitian ini mendukung penelitian Solikhah (2014) yang menunjukkan bahwa sikap terhadap perilaku mempengaruhi niat untuk mengejar karir CPA yang didasari keuntungan dalam peningkatan karir sebagai akuntan. Demikian pula dengan penelitian yang dilakukan oleh Felton et al. (1995) membuktikan bahwa mahasiswa yang berniat menjadi chartered accountant memiliki sikap yang positif terhadap karier pada profesi tersebut. Kedua penelitian ini menjelaskan bahwa variabel sikap terhadap perilaku 
berpengaruh positif terhadap niat mahasiswa akuntansi berkarir sebagai akuntan diluar negeri. Hasil penelitian ini juga mengkonfirmasi teori TPB yang telah sering digunakan didalam penelitian untuk menguji niat berperilaku, yang menyatakan bahwa sikap terhadap perilaku berpengaruh merupakan salah satu faktor penentu niat perilaku seseorang.

\section{Norma Subjektif dan niat mahasiswa berkarir sebagai akuntan di luar negeri}

Hipotesis kedua yang menyatakan norma subjektif berpengaruh terhadap niat mahasiswa berkarir sebagai akuntan di luar negeri secara empiris didukung. Hasil penelitian ini menunjukkan bahwa mahasiswa jurusan akuntansi dipengaruhi oleh orang-orang disekitar mereka seperti orang tua, keluarga, sahabat, teman, dosen dan ahli akuntan untuk memilih berkarir sebagai akuntan di luar negeri. Semakin besar masukan dan pendapat yang diterima responden dari orang-orang di sekitar maka semakin besar pula niat responden untuk berkarir sebagai akuntan di luar negeri. Hal ini dapat disebabkan karena adanya motivasi yang didapatkan dari orang-orang sekitar, dosen serta pandangan positif responden terhadap ahli akuntan. Ketika orang-orang disekitar responden menyarankan dan memotivasi untuk berkarir sebagai akuntan diluar negeri maka, niat responden untuk berkarir sebagai akuntan akan semakin besar.

Hasil penelitian ini juga mendukung penelitian Solikhah (2014) menjelaskan bahwa norma subyektif mempengaruhi niat untuk mengejar karir sebagai CPA. Demikian pula dengan penelitian yang dilakukan oleh Sulistiani (2012) juga menjelaskan faktor norma subjektif memiliki pengaruh yang signifikan terhadap niat mahasiswa akuntansi untuk berkarier sebagai akuntan publik.

Hasil penelitian ini juga mengkonfirmasi teori TPB, yang memaparkan bahwa norma subyektif merupakan fungsi yang didasarkan oleh belief yang disebut sebagai normative beliefs. Keyakinan yang didapatkan mahasiswa jurusan akuntansi ini berasal dari saran dan motivasi orang-orang disekitarnya yang menyebabkan niat untuk berkarir sebagai akuntan di luar negeri semakin besar.

\section{Kontrol perilaku persepsian dan niat mahasiswa akuntansi berkarir sebagai akuntan.}

Hipotesis ketiga yang menyatakan bahwa kontrol perilaku persepsian berpengaruh terhahap niat mahasiswa akuntansi berkarir sebagai akuntan secara empiris ditolak. Hasil penelitian ini menunjukkan bahwa mahasiswa jurusan akuntansi dalam memilih berkarir sebagai akuntan di luar negeri dipengaruhi oleh hambatan yang ada dalam prosesnya untuk menjadi seorang akutan di luar negeri, semakin besar hambatan yang dirasakan oleh responden untuk berkarir sebagai akuntan diluar negeri, maka semakin kecil niat mereka untuk berkarir sebagai akuntan diluar negeri. Namun, kuatnya keyakinan positif dan saran serta motivasi dari orang-orang sekitar yang terdapat didalam dua variabel sikap terhadap perilaku dan norma subjektif menyebabkan hambatan yang dirasakan oleh responden untuk berkarir sebagai akuntan tidak terlalu kuat dirasakan. Hal ini dapat disebabkan karena hambatan yang dihadapi seperti perbedaan budaya, bahasa, persaingan dengan akuntan di lain, serta jam kerja sebagai akuntan yang tinggi, yang dianggap responden merupakan hambatan yang cukup sulit untuk dihadapi.

Hasil penelitian ini mendukung penelitian yang dilakukan Sugahara dan Boland (2006) yang menjelaskan bahwa jam kerja yang tinggi menjadi hambatan bagi responden untuk berkarir sebagai akuntan diluar negeri, hal ini disebabkan karena responden merasa waktu bersama keluarga akan berkurang apabila berkarir sebagai akuntan di luar negeri.

Hasil penelitian berhasil mengkonfirmasi teori TPB yang menyatakan faktor hambatan dalam variabel kontrol perilaku persepsian mempengaruhi niat akuntan dalam memilih berkarir sebagai akuntan diluar negeri, namun dalam penelitian ini hambatan yang dirasakan tidak lebih kuat jika dibandingkan dengan keyakinan positif dan saran dan motivasi 
yang didapatkan oleh responden, sehingga responden tetap memiliki niat untuk berkarir sebagai akuntan diluar negeri.

\section{PENUTUP}

\section{Simpulan}

Berdasarkan pada hasil dan pembahasan, maka dapat disimpulkan sebagai berikut:

1) Sikap terhadap perilaku terbukti berpengaruh terhadap niat mahasiswa akuntansi untuk berkarir sebagai akuntan di luar negeri. Ketika mahasiswa jurusan akuntansi memiliki keyakinan positif terhadap berkarir sebagai akuntan di luar negeri, maka semakin besar pula niat responden untuk berkarir sebagai akuntan di luar negeri.

2) Norma Subjektif berpengaruh terhadap niat mahasiswa akuntansi untuk berkarir sebagai akuntan di luar negeri Ketika mahasiswa jurusan akuntansi mempertimbangkan pendapat, saran dan motivasi dari orang- orang yang ada disekitar seperti orang tua, keluarga, dosen, rekan sekerja, sahabat, teman dan ahli akuntansi, maka semakin besar pula niat responden untuk berkarir sebagai akuntan diluar negeri.

3) Persepsi hambatan dalam kontrol perilaku persepsian bukan menjadi faktor yang mempengaruhi niat mahasiswa akuntansi untuk berkarir sebagai akuntan di luar negeri.

\section{Implikasi Penelitian}

Secara teoritis, hasil penelitian ini berimplikasi pada pengembangan akuntansi keperilakuan, yang mana dalam penelitian ini faktor dari Theory of Planned Behavior (TPB) yaitu sikap terhadap perilaku, norma subjektif, dan kontrol perilaku persepsian yang langsung mempengaruhi perilaku individu. Hasil penelitian ini diharapkan dapat semakin memotivasi mahasiswa untuk terus mengembangkan kemampuan mereka baik verbal dan non verbal agar dapat bersaing dengan akuntan lain dei era MEA.

Penelitian ini belum bisa digeneralisasi karena sampel penelitian terbatas hanya pada mahasiswa tingkat akhir D3 dan S1 Jurusan Akuntansi di Kota Bengkulu dan penelitian ini menggunakan metode penyebaran kuesioner tanpa dilengkapi dengan wawancara atau pertanyaan lisan, keterbatasan yang melekat pada data yang diperoleh melalui kuesioner adalah perbedaan persepsi penulis dengan responden dalam penelitian. Untuk penelitian selanjutnya dapat memperluas objek penelitan dan menguji beberapa variabel lain seperti kompetensi yang dimiliki oleh mahasiswa jurusan akuntansi.

\section{DAFTAR PUSTAKA}

Abdillah, Willy dan Jogiyanto. 2015. Partial Least Square (PLS) - Alternatif Structural Equation Modeling (SEM) dalam Penelitian Bisnis. Yogyakarta: CV. Andi Offset.

Ajzen, Icek. 1991." Theory of Planned Behavior". Organizational Behavior and Human Decision Processes 50, 179-211 (1991).

.2002. Perceived Behavioral Control, Self-Efficacy, Locus of Control, and the Theory of Planned Behavior. Journal ofApplied Social Psychology, 2002, 32, 4, pp. 665-683.

2006. The theory of planned behavior. Retrieved January, 09, 2011 from:

http://people.umass.edu/aizen/tpb.htm . 2012. "The Theory of Planned Behavior". In P. A. M. Lange, A. W. 
Kruglanski \& E. T. Higgins (Eds.)". Handbook of Theories of Social psychology (Vol. 1, pp. 438-459). London, UK: Sage

Ajzen, I. dan Driver, B.L." Application of the Theory of Planned Behavior to Leisure Choice. Journal of Leisure Research 24(3):207-224 · January 1992

Amin, Hanudin, Abdul Rahim Abdul Rahman, dan T.Ramayah. 2009." What makes Undergraduate Student Enroll into an Elective Course? The case of Islamic Accounting". International Journal of Islamic and Middle Eastern Finance and Management, Vol.2, No. 4, h. 289-304.

Ali, Syukriah, Rosliza Md Zani, and Kartini Kasim.2014. "Intention - Behaviour Relations: A Conceptual and Literature Review". Research Journal of Finance and Accounting ISSN 2222-1697 (Paper) ISSN 2222-2847 (Online) Vol.5, No.19, 2014.

Amelie, Siska F.Diel.2014.Perbandingan Gaji Pekerja RI dengan negara lain di ASEAN. Liputan 6 (23 November 2014)

Astuti, Anita.2014. "Faktor-faktor yang mempengaruhi Mahasiswa Akuntansi dalam memilih Karir sebagai Akuntan Publik pada Mahasiswa Akuntansi Universitas Kristen Satya Wacana Salatiga”. Perpustakaan Universitas Kristen Satya Wacana Salatiga.

Association of Southeast Asian Nations. 2009." ASEAN Mutual Recognition Arrangement Framework on Accountancy Services. http://investasean.asean.org. Pada tanggal 16 November 2016, jam 11.35

Badingatus, Solikhah.2014."An application of theory of planned behavior towards CPA career in Indonesia. Procedia - Social and Behavioral Sciences 164 (2014) 397 - 402.

Christanti, D. (2008). Sikap ataukah significant others yang dapat mempengaruhi intensi membuang sampah sesuai jenisnya. Jurnal Ilmiah Psikologi Manasa, 2(2), 129-145.

Chin, W. W. 1998. The Partial Least Squares Approach to Structural Equation Modeling. In G. A. Marcoulides (Ed.). Modern Methods for Business Research (295-336). Mahwah, New Jersey, London: Lawrence Eribaum Associates.

Donna D. Bobek and Richard C. Hatfield. 2003. An Investigation of the Theory of Planned Behavior and the Role of Moral Obligation in Tax Compliance. Behavioral Research in Accounting: February 2003, Vol. 15, No. 1, pp. 13-38.

Felton et.al.1995. A Theory of Reasoned Action Model of the Chartered Accountant Career Choice. Journal of Accounting Education, Vol. 13, No. 1, pp. 1-19, 1995.

Fishbein, M., \& Ajzen, I. (1980). Understanding attitudes and predicting social behavior. New Jersey: Prentice Hall Engelwood Cliffs.

Fishbein, M., \& Ajzen, I. (1975). Belief, attitude, intention, and behavior: An introduction to theory and research. Philippines: Addison-Wesley Publishing Company.

Ghozali, Imam. 2006. Aplikasi Analisis Multivariate dengan Program SPSS. Semarang: Badan Penerbit Universitas Diponegoro.

Howard,F. Buchan.2005." Ethical Decision Making in the Public Accounting Profession: An Extension of Ajzen's Theory of Planned Behavior". Journal of Business Ethics (2005) 61: $165-181$

Ikatan Akuntan Indonesia (IAI). (2014)."Bersiap Diri Menyambut Pasar Tunggal ASEAN".Diakses melalui http://www.iaiglobal.or.id. Pada tanggal 16 November 2016, jam 14.35.

Indriantoro, dan Supomo, 2002.Metodologi Penelitian Bisnis untuk Akuntansi dan Manajemen, Edisi Pertama, BPFE-Yogyakarta, Yogyakarta.

Otoritas Jasa dan Keuangan. 2015. Peluang dan tantangan akuntan di Era MEA oleh Ilya Avianti. Simposium Nasional Akuntansi (SNA) XVIII Medan, 17 September 2015 
Sugahara dan Boland.2006. "ISSUE 2 Perceptions of the certified public accountants by accounting and non-accounting tertiary students in Japan". Asian Review of Accounting Vol. 14 No. 1/2, 2006 pp. 149-167. . (2006). "The Role Perceptions toward the Accounting

Proffesions by Japanese Tertiary Bussines Students in the Process of Career Choice". Paper of Research Society of Commerce and Economics. Vol. XXXXVI No. 2.

Sugahara, S., G. Boland, and A. Cilloni. 2008. Factors Influencing Students' Choice of an Accounting Major in Australia. Accounting Education: An International Journal (Vol. 17,supplement) 37-54.

Sugiyono. (2012). Metode Penelitian Kuantitatif, Kualitatif, dan R\&D. Cetakan ke-17. Bandung: Alfabeta.

Sukirno, R. S. H., \& Sutarmanto, H. (2007). Faktor-faktor yang mempengaruhi intensi membeli produk wayang kulit pada masyarakat suku Jawa. Psikologika, 24, 119-131

Sulistiani, Dewi. 2012. "Faktor- Faktor yang memengaruhi Niat Mahasiswa Akuntansi untuk berkarir sebagai Akuntan Publik: Aplikasi Theory of Planned Behavior( Studi Empiris pada Mahasiswa Universitas Diponegoro)". Skripsi Sarjana pada Universitas Diponegoro.

Sumaryono.2015. "Pengujian Pengaruh Theory of Planned Behavior dan tingkat pemahaman mengenai Chartered Accountant terhadap Niat Mahasiswa untuk mengambil sertifikasi Chartered Accountant (Studi kasus pada Mahasiswa Akuntansi Angkatan 2012 dan 2013 Universitas Negeri Yogyakarta)'.Skripsi Sarjana pada Universitas Negeri Yogyakarta. 